\title{
A Game-Theoretic Approach to Model Interruptible Loads: Application to Micro-Grid Planning
}

\author{
Soheil Mohseni, Alan C. Brent, Daniel Burmester, Will Browne \\ School of Engineering and Computer Science, Victoria University of Wellington, Wellington 6140, New Zealand \\ Email: \{soheil.mohseni, alan.brent, daniel.burmester, will.browne\}@vuw.ac.nz
}

\begin{abstract}
This paper proposes a novel modeling approach for the efficient integration of demand response (DR) resources into the equipment capacity-planning problem of micro-grids based on Game Theory. The main advantage of this approach is that it determines the DR events based on the day-ahead system state estimates (in contrast to the conventional exogenetic demand-side management approaches), whilst protecting the customers' welfare. A battery-less, $100 \%$-renewable, gridindependent micro-grid is conceptualized, and the town Ohakune, New Zealand is used as a test-case to evaluate the effectiveness of the proposed modeling framework. The numerical simulation results indicate that the proposed approach achieves substantial (12.59\%) savings in the life-cycle cost of the target system, as compared to the case where a timeof-use DR is implemented.
\end{abstract}

Keywords-Microgrids, Demand-side management, Power system planning, Distributed power generation, Electric vehicles.

\section{INTRODUCTION}

To reduce greenhouse gas emissions, efforts are underway to scale up zero-emissions electricity generation, whilst building green transportation infrastructure. On the other hand, the demand for electricity is rising. That is, New Zealand's electricity transmission network (National Grid) owner and operator, Transpower, has projected that by 2050 , the country's electricity demand will double as a result of decarbonizing the energy economy [1]. In this sense, smart renewable and sustainable energy systems (RSESs), such as micro-grids (MGs), energy hubs, virtual power plants, and so forth, have been proposed as interventions to facilitate the management of the volatility inherent in power outputs from weather-dependent renewable energy generators, notably solar and wind power, as well as to manage demand [2]. These RSESs not only make the intermittent, highly distributed renewable power visible for the system operator, but also significantly improve the cost-efficiency of renewable energy solutions through: (1) utilizing a variety of energy storage technologies, and (2) benefitting from the opportunities offered under the smart grid milieu - most significantly, the mass adoption of demand-side management (DSM) schemes.

The optimal planning of the infrastructure investments in RSESs could potentially play a critical role in accelerating the: (1) financing of those investments on the supply side, and (2) uptake of environmentally-friendly technologies, such as green vehicles, on the demand side. Additionally, such systems can help boost the participation of the end-users of electricity in energy demand management schemes, by allowing them to take advantage of the incentives offered by the utility for their collaborative consumption of energy. In this light, few research studies have been carried out to estimate the impact of demand response (DR) scheduling using a variety of DR provision approaches - on the wholelife cost of the RSESs in their long-term economic planning phase [3]-[5]. Table I presents a summary of the studies concerning the deployment of DR plans, while optimally designing RSESs [6]-[10].

All the studies to date that integrate energy demand management plans into the equipment capacity-planning problems of RSESs (mentioned in Table I) have failed to address behavioral risk factors in the realization of their designed DSM procurement frameworks in real-time. Hence, suffering from epistemic uncertainty, their suggested DR delivery structures cannot be relied on to obtain pre-set load reduction goals in practice. Accordingly, the objective of this paper is twofold: (1) to model the consumers' behavior in contributing to the load reduction in response to the utility's DSM strategies using Game Theory, and subsequently (2) to incorporate the developed game-theoretic DR program in the optimal equipment capacity-planning of an MG.

TABLE I. REVIEW OF STUdies MODELING THE IMPACT OF DSM ON THE LONG-TERM PLANNING OF RSESS

\begin{tabular}{|c|c|c|c|c|}
\hline System architecture & Responsive loads & $\begin{array}{c}\text { DSM } \\
\text { technique }\end{array}$ & Optimizer & Ref. \\
\hline Grid-tied photovoltaic/battery & $\begin{array}{c}\text { Smart appliances of a smart home and electric } \\
\text { vehicle-charging loads }\end{array}$ & Time-of-use & $\begin{array}{c}\text { Mixed-integer } \\
\text { linear programming }\end{array}$ & Erdinc et al. [6] \\
\hline On-grid wind/battery & Smart appliances of a smart home & $\begin{array}{l}\text { Real-time } \\
\text { pricing }\end{array}$ & $\begin{array}{c}\text { Particle swarm } \\
\text { optimization }\end{array}$ & $\begin{array}{c}\text { Kahrobaee et al. } \\
\text { [7] }\end{array}$ \\
\hline $\begin{array}{c}\text { Off-grid } \\
\text { photovoltaic/wind/battery/diesel }\end{array}$ & $\begin{array}{l}\text { Air conditioners with a pre-determined } \\
\text { maximum capacity }\end{array}$ & $\begin{array}{l}\text { Direct load } \\
\text { control }\end{array}$ & $\begin{array}{c}\text { Nonlinear } \\
\text { programming }\end{array}$ & Zhu et al. [8] \\
\hline $\begin{array}{c}\text { Stand-alone } \\
\text { photovoltaic/wind/hydro/biogas/battery }\end{array}$ & $\begin{array}{l}\text { Smart appliances at the domestic, commercial, } \\
\text { agricultural, and community levels }\end{array}$ & $\begin{array}{l}\text { Direct load } \\
\text { control }\end{array}$ & $\begin{array}{l}\text { Discrete harmony } \\
\text { search }\end{array}$ & $\begin{array}{l}\text { Chauhan and } \\
\text { Saini [9] }\end{array}$ \\
\hline $\begin{array}{l}\text { Grid-connected photovoltaic/fuel } \\
\text { cell/battery/super-capacitor }\end{array}$ & $\begin{array}{l}\text { Ten per cent of the total electrical load at each } \\
\text { hour }\end{array}$ & $\begin{array}{l}\text { Interruptible } \\
\text { loads }\end{array}$ & $\begin{array}{l}\text { Particle swarm } \\
\text { optimization }\end{array}$ & $\begin{array}{c}\text { Hassanzadehfard } \\
\text { et al. [10] }\end{array}$ \\
\hline
\end{tabular}




\section{DesCRIPTION OF THE MG Test-CASE System}

A conceptual MG model, whose configuration is shown in Fig. 1, is employed to evaluate the effectiveness of the proposed game-theoretic optimal investment planning method. It accommodates solar photovoltaic (PV) panels, wind turbines (WTs), and micro-hydro power plants (MHPPs) to exploit renewable energy sources (RESs) for electricity generation. The system is backed-up with a hybrid energy storage system integrating a hydrogen $\left(\mathrm{H}_{2}\right)$-based energy storage system (constituted of an electrolyzer, an $\mathrm{H}_{2}$ reservoir, and fuel cell stacks), and super-capacitor (SC) modules. Five different load aggregators, namely the residential, plug-in hybrid electric vehicle (PHEV)-charging, industrial, agricultural, and commercial aggregation agents are envisioned to act as the interface between the electricity consumers and the DSM market - to reap scale economies. An electric vehicle charging infrastructure, which is composed of electric vehicle supply equipment (EVSE), serves the purpose of charging of PHEV batteries. Additionally, some power converters are adopted to couple the MG components and loads to a common busbar. The mathematical modeling of the energy generation, storage, and conversion equipment employed within the MG structure is detailed in our previous papers [4], [11].

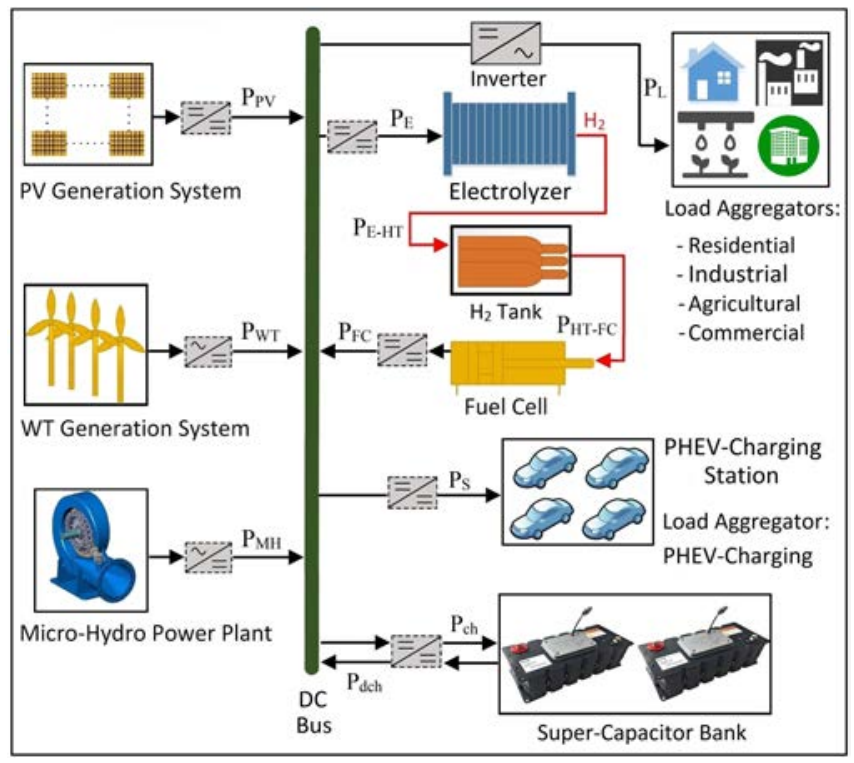

Fig. 1. Architecture and electricity flow of the conceptualized MG.

\section{GAME-TheORETIC MODELING OF DR PROGRAMS}

This section formulates the proposed game-theoretic approach to model the DR programs using the interruptible loads. In this regard, it is assumed that five independent load aggregators serve the purpose of aggregating different types of loads, including residential, industrial, agricultural, commercial, and PHEV-charging loads. These aggregation agents join the demand response resources of the customers of the same type, and together have the authority to act on behalf of them in the demand response market. This has led to a cooperative (coalitional), non-zero-sum, two-player game, where the outcome could potentially only have net results greater than zero, benefitting both sides. At the same time, this strategic game falls in the category of Stackelberg competition, where the utility as the leader moves first - and knows ex-ante that the followers notice its moves - and then the follower aggregators move sequentially.
For the sake of simplicity, we first formulate the problem considering only one aggregation agent in a monopolistic situation of power supply. Suppose $\operatorname{In}(\delta, x)$ represents the cost imposed on the utility by rewarding the aggregator of the type $\delta$ for its participation in the DSM program and reducing its load power consumption by $x \mathrm{~kW}$. In this situation, the real amount of incentive payments received by the considered aggregator can be expressed as follows [12], [13]:

$$
\operatorname{In}(\delta, x, y)=y-c(\delta, x)
$$

where $y$ denotes the amount of financial incentive paid to the aggregation agent in return for the contributions made to the energy-use reduction, while the term $c(\delta, x)$ represents the cost imposed on the aggregator, which will be discussed in more detail in the following section. As one would expect, the aggregator would consider engaging in the DR schemes only if $\operatorname{In}(\delta, x, y)>0$.

In this context, the profit gained by the utility for not supplying part of the total loads during the peak consumption hours can be calculated as follows [12], [13]:

$$
\operatorname{Pr}(x, y)=\lambda x-y
$$

where $\lambda$ denotes the per-unit cost of not serving the loads during the time windows labeled as peak periods $(\$ / \mathrm{kW})$. Power utilities have access to such information (hereafter termed 'worth of load interruption') based on power system state estimation studies. Accordingly, it is assumed that the value of $\lambda$ is available for every time period $(1 \mathrm{~h})$ of energy consumption for different months of the year.

The utility aims to maximize its expected profit, which could be expressed as [12], [13]:

$$
\max _{x, y}(\lambda x-y) \text {. }
$$

On the other hand, the customers have the freedom to decide whether or not to be involved in any DR event called by the utility. Hence, the utility will have to offer appealing incentives to the customers (here, aggregators) to foster their involvement in the energy demand management plans. The reason is that load curtailment comes at the cost of reducing the customers' comfort level to some degree, which could be modeled as follows [12], [13]:

$$
c(\delta, x)=c_{1} x^{2}+c_{2} x-c_{2} \delta x,
$$

where $c_{1}$ and $c_{2}$ represent cost factors, whose values could be determined through the utility's cost-benefit analysis on the DR plan, whose values are assumed to be available. Also, the variable $\delta$ (which indicates the customer type), is normalized in the range $[0,1]$; the greater the value of $\delta$, the greater the willingness of customers to participate in the DR mechanisms - for the customers who are totally unwilling to participate in the program, $\delta \rightarrow 0$.

Taking the derivative of (4) w.r.t. the amount of load reduction the aggregator is looking to deliver, the marginal cost imposed on the aggregator - in the form of reduced convenience of its customers - could be derived as [12], [13]:

$$
\frac{\partial c}{\partial x}=2 c_{1} x+c_{2}-c_{2} \delta
$$

The presented game-theoretic approach to model DR resources can be easily generalized to include more than one aggregator and/or utility. Since the focus of this study is on developing a grid-independent sustainable energy system, we generalize the above model to include several aggregators - in 
compliance with different aggregator categories mentioned above - in the presence of only one utility, which monopolistically controls the electricity generation. Note that despite the monopolistic nature of electricity supply, the provision of DR services is oriented by market mechanisms, where the customers are free to choose whether to engage in such programs. Therefore, the devised DR plan is, in fact, structured as a market-directed incentive-centered plan.

Assuming there are $N$ aggregation agents in the system, the above-described DR procurement model can be generalized as follows. The amount of incentives received by the aggregators can be calculated as [12], [13]:

$$
I n_{j}=y_{j}-\left(c_{1} x_{j}^{2}+c_{2} x_{j}-c_{2} \delta_{j} x_{j}\right), \quad \forall j \in\{1,2,3, \ldots, N\} .
$$

On the other hand, the utility's profit function, which is to be maximized subject to the non-negativity of (6), as well as the payment of incentives to aggregators in step with their engagement rate and the category of their loads, can be determined by (7) [12], [13].

$$
\operatorname{Pr}=\sum_{j=1}^{N}\left(\lambda_{j} x_{j}-y_{j}\right), \quad \forall j \in\{1,2,3, \ldots, N\} .
$$

As stated above, the conceptualized game is a Stackelberg game between the utility and the aggregators, which is led by the utility by taking the first move. A classic 'tit-for-tat' strategy is employed to model the behavior of the aggregators in response to the utility's moves in the course of the game. In a tit-for-tat strategy (which can be highly cooperative, assuming that players would act rationally), an agent cooperates in the first round of the game, then duplicates the opponent's last move [14]. In this light, reducing the incentives paid for energy-use reduction is marked as a noncooperative turn. As expected, in such a case, the aggregators will reduce their participation in the next move in retaliation to the utility's previous move.

\section{GAME THEORY-CENTERED MG PlanNING METHOD}

The proposed method uses the net present cost (NPC) concept to project the cost of the conceptualized system, and utilizes the loss of power supply probability (LPSP) indicator - which is set at LPSP $=0.01$ - to measure the performance of the optimized system in terms of power supply consistency. In addition, an hourly-basis, year-long operational timeframe $(8760-\mathrm{h})$ is considered for the operation of the system. The method also uses the game-theoretic DSM provision put forward in Section III to model the delivery of the DR resources. Moreover, as the chosen optimizer, the genetic algorithm - which is a well-established optimization algorithm in this area - serves the purpose of minimizing the formulated long-term MG capital planning problem. For reasons of space, the reader is referred to [15] and the references cited therein, for an introduction to the NPC method, the LPSP index, and the genetic algorithm optimizer. The game-theoretic DR scheduling procedure, which is embedded within the pre-defined cycle-charging operational strategy of the MG system, starts by sending the utility's proposed incentives on a day-ahead basis to the aggregators. The aggregators then decide whether or not to accept the offer based on the pre-defined game rules and their elasticity levels for load interruption - with respect to their pre-specified daily limits of interruptible power. Finally, within each 24-h time interval, the central DR market mechanism dispatches the DR resources, whose requested levels of incentives are satisfied at the market-clearing price determined by the Nash equilibrium of the game.

\section{Simulation ResUlts AND DiscUSSION}

\section{A. Case Study Site}

The conceptualized off-grid MG model was considered to decarbonize the economy of the town Ohakune, New Zealand (latitude $39.4180^{\circ} \mathrm{S}$, longitude $175.3985^{\circ} \mathrm{E}$ ). The town has a permanent population of around 1,000 people, while during the winter ski season the population rises to about 8,500 . The community residing in the town has experienced unaffordable bills driven by congestion within the regional distribution network connecting them to the National Grid [16].

\section{B. Input Data and Assumptions}

The techno-economic specifications of the components put into service in the MG are listed in Table II [17]-[23]. Throughout this paper, all the costs are converted to US dollars. The climatic profiles, including the solar irradiance, wind speed, and the streamflow of the Mangawhero River were sourced from the New Zealand's National Institute of Water and Atmospheric Research (NIWA) database [24].

In this respect, the historical climatological data collected for the considered locations were averaged at 1-h intervals over a 10-year period, between 2009 and 2018. The measured electricity demand data set was first collected from [25], and then broken down into the industrial, commercial, agricultural, and residential data categories in accordance with the records of different load profiles in New Zealand given in [26]. In addition, a fleet of 150 light-duty, commuter PHEVs, whose technical characteristics and the commuting behavior of their owners are as those considered in [27], shape the energy consumption profile of the PHEV charging station. The hourly year-long profile for the aggregate load demand was characterized with an average of 11.08 $\mathrm{MWh}$ /day (averaged over one year) and a peak demand of $1.49 \mathrm{MW}$, occurring between 6 and 7 p.m. on one of the winter days. The real discount rate and the MG's projected service life were assumed as $6 \%$ and 20 years, respectively.

As the input data to the DR scheduling level of the proposed investment planning modeling framework, the predefined values of the worth of load interruption $(\lambda)$ and the financial incentives offered to the aggregation agents $(y)$ for each month of the year are given in Fig. 2. The assumed crossprice elasticities of demand $(\delta)$ for different load aggregation agents, as well as their daily limits of interruptible power (DL) - specified as $10 \%$ of the load powers aggregated over 24 hours for each load type - are presented in Table III. The expected values of the variables $\lambda$ and $y$, as well as the aggregators' cost function coefficients, were chosen based on the results obtained in [13] for a broad range of regimes. The time intervals marked as peak usage hours are identified 24 hours ahead of schedule - and are not restricted to occurring only at certain, pre-defined hours of the day - which helps better handle the uncertainties arising from the conceptualized $100 \%$-renewable MG. In addition, appropriate data sets were used to train the game-theoretic model using the supportvector-machine (SVM) learning algorithm - to enable the agents to handle the edge cases by actively responding to the changes in incentives offered by the utility. 
TABLE II. TECHNO-ECONOMIC SPECIFICATIONS OF THE MG EQUIPMENT

\begin{tabular}{|c|c|c|c|c|c|}
\hline Component & $\begin{array}{c}\text { Rated } \\
\text { size }\end{array}$ & $\begin{array}{c}\text { Capital } \\
\text { cost }\end{array}$ & $\begin{array}{l}\text { Replace- } \\
\text { ment cost }\end{array}$ & $\begin{array}{c}\text { O\&M } \\
\text { cost }\end{array}$ & $\begin{array}{l}\text { Life- } \\
\text { time } \\
\text { (year) }\end{array}$ \\
\hline PV panel & $\begin{array}{l}175 \\
W\end{array}$ & $\begin{array}{l}\$ 375 \\
\text { /unit }\end{array}$ & $\begin{array}{l}\$ 375 \\
\text { /unit }\end{array}$ & $\begin{array}{c}\$ 7.5 \\
\text { /unit-yr }\end{array}$ & 20 \\
\hline WT & $\begin{array}{l}100 \\
\mathrm{~kW}\end{array}$ & $\begin{array}{c}\$ 110000 \\
\text { /unit }\end{array}$ & $\begin{array}{c}\$ 70000 \\
\text { /unit }\end{array}$ & $\begin{array}{l}\$ 2200 \\
\text { /unit-yr }\end{array}$ & 20 \\
\hline MHPP & $\begin{array}{c}49 \\
\mathrm{~kW}\end{array}$ & $\begin{array}{c}\$ 55000 \\
\text { /unit }\end{array}$ & $\begin{array}{c}\$ 55000 \\
\text { /unit }\end{array}$ & $\begin{array}{l}\$ \$ 1100 \\
\text { /unit-yr }\end{array}$ & 25 \\
\hline EVSE & $\begin{array}{c}22 \\
\mathrm{~kW}\end{array}$ & $\begin{array}{l}\$ 4000 \\
\text { /unit }\end{array}$ & $\begin{array}{l}\$ 4000 \\
\text { /unit }\end{array}$ & $\begin{array}{c}\$ 20 \\
\text { /unit-yr }\end{array}$ & 20 \\
\hline $\mathrm{SC}$ & $\begin{array}{l}3.2 \\
\text { Wh }\end{array}$ & \$62/unit & \$62/unit & $\begin{array}{c}1.24 \\
\text { /unit-yr }\end{array}$ & 15 \\
\hline Fuel cell & $5 \mathrm{~kW}$ & $\begin{array}{l}\$ 4000 \\
\text { /unit }\end{array}$ & $\begin{array}{l}\$ 4000 \\
\text { /unit }\end{array}$ & $\begin{array}{c}\$ 60 \\
\text { /unit-yr }\end{array}$ & 5 \\
\hline Electrolyzer & $1 \mathrm{~kW}$ & $\begin{array}{l}\$ 1000 \\
/ \mathrm{kW}\end{array}$ & $\begin{array}{c}\$ 1000 \\
/ \mathrm{kW}\end{array}$ & $\begin{array}{c}\$ 20 \\
/ \mathrm{kW}-\mathrm{yr}\end{array}$ & 15 \\
\hline $\mathrm{H}_{2}$ tank & $1 \mathrm{~kg}$ & $\begin{array}{c}\$ 470 \\
/ \mathrm{kg}\end{array}$ & $\begin{array}{c}\$ 470 \\
/ \mathrm{kg}\end{array}$ & $\begin{array}{c}\$ 9.4 \\
/ \mathrm{kg}-\mathrm{yr}\end{array}$ & 20 \\
\hline Inverter & $1 \mathrm{~kW}$ & $\begin{array}{l}\$ 750 \\
/ \mathrm{kW}\end{array}$ & $\begin{array}{l}\$ 750 \\
/ \mathrm{kW}\end{array}$ & $\begin{array}{c}\$ 15 \\
/ \mathrm{kW}-\mathrm{yr}\end{array}$ & 15 \\
\hline
\end{tabular}

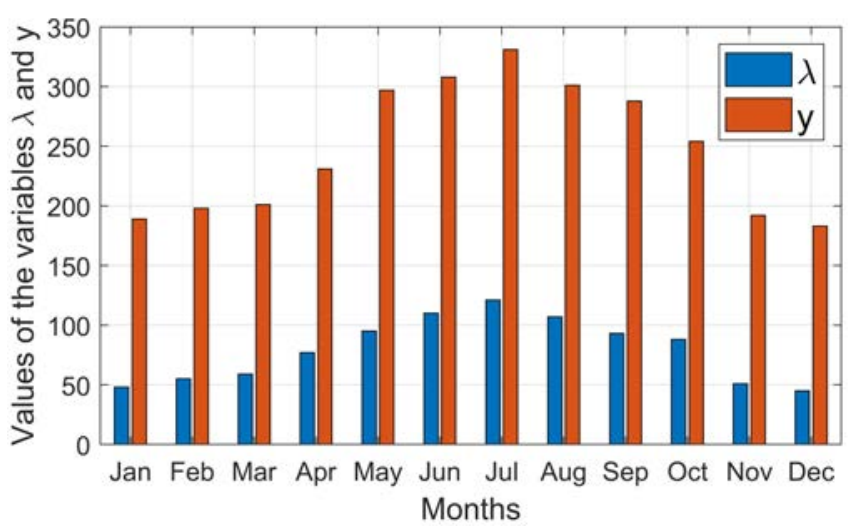

Fig. 2. Pre-defined monthly values of the variables $\lambda$ and $y$.

TABLE III. AgENTS' COST FunCTION COEFFICIENTS AND SPECIFICATIONS

\begin{tabular}{ccccc}
\hline Aggregator & $c_{1}$ & $c_{2}$ & $\delta$ & $\mathrm{DL}(\mathrm{kW})$ \\
\hline Residential & 1.08 & 11.49 & 0.48 & 223.58 \\
\hline Commercial & 1.04 & 11.31 & 0.51 & 156.47 \\
\hline Industrial & 0.99 & 11.71 & 0.57 & 268.20 \\
\hline Agricultural & 0.95 & 11.25 & 0.63 & 67.04 \\
\hline $\begin{array}{c}\text { PHEV- } \\
\text { Charging }\end{array}$ & 0.91 & 11.40 & 0.76 & 29.8 \\
\hline
\end{tabular}

\section{Capacity-Planning Results}

The numerical simulation was conducted on the Intel ${ }^{\circledR}$ Core $^{\mathrm{TM}}$ i7-8700, 3.20 GHz CPU with a RAM of $16 \mathrm{~GB}$ using the MATLAB software. Table IV reports the results of the optimized long-term capital plan for installing the conceptualized MG at the site under study in terms of the size of the equipment. The optimized whole-life cost of the system is found to be $\$ 9,728,403$.

TABLE IV. MG DESIGN OPTIMIZATION RESULTS

\begin{tabular}{ccccccccc}
\hline $\begin{array}{c}\text { PV } \\
(\text { no })\end{array}$ & $\begin{array}{c}\text { WT } \\
(\text { no })\end{array}$ & $\begin{array}{c}\text { MH- } \\
\text { PP })\end{array}$ & $\begin{array}{c}\text { FC } \\
(\text { no })\end{array}$ & $\begin{array}{c}\text { SC } \\
(\text { no })\end{array}$ & $\begin{array}{c}\text { Elec. } \\
(\mathrm{kW})\end{array}$ & $\begin{array}{c}\text { Tank } \\
(\mathrm{kg})\end{array}$ & $\begin{array}{c}\text { Inv. } \\
(\mathrm{kW})\end{array}$ & $\begin{array}{c}\text { EV- } \\
\text { SE } \\
(\mathrm{no})\end{array}$ \\
\hline 1388 & 11 & 12 & 172 & 24091 & 1063 & 680 & 1321 & 3 \\
\hline
\end{tabular}

To verify the efficacy of the proposed game-theoretic approach for modeling the DSM resources, two cases were considered, where the system was designed (1) by considering a DR delivery service, where $10 \%$ of the loads during the predefined peak consumption hours (between 5 and 9 p.m.) could be interrupted, and (2) without implementing any interruptible loads. The results obtained under these two cases are reported and compared with the base-case scenario results in Table V. In the table, the game-theoretic, non-game-theoretic DRinfused scenarios are respectively represented by 'GT-DR' and 'NGT-DR', while the scenario of not implementing any DR strategies is represented by 'NO-DR'. In the three scenarios, the optimal number of the PV panels was equal to 1,388 , which is because solar is found to be the most affordable energy resource (up to the saturation point) - and changing its size was not found as an optimum solution. The table indicates that the implementation of the suggested Game Theory-centered DR provision scheme achieves cost-savings of $12.59 \%$ (equating to $\$ 1,400,638$ ) and $19.37 \%$ (equating to $\$ 2,337,068$ ) over the MG's lifetime compared with nongame-theoretic modeling of the DR resources and not running any DR programs, respectively. Hence, the proposed model substantially contributes to the affordability of the envisioned plan and could act as a catalyst for the realization of the proposed MG system.

TABLE V. IMPACT ASSESSMENT OF THE PROPOSED DSM APPROACH

\begin{tabular}{ccccccccc}
\hline Scen. & $\begin{array}{c}\text { WT } \\
(\mathrm{no})\end{array}$ & $\begin{array}{c}\text { MH- } \\
\text { PP } \\
(\mathrm{no})\end{array}$ & $\begin{array}{c}\text { FC } \\
(\mathrm{no})\end{array}$ & $\begin{array}{c}\text { SC } \\
(\mathrm{no})\end{array}$ & $\begin{array}{c}\text { Elec. } \\
(\mathrm{kW})\end{array}$ & $\begin{array}{c}\text { Tank } \\
(\mathrm{kg})\end{array}$ & $\begin{array}{c}\text { Inv. } \\
(\mathrm{kW})\end{array}$ & $\begin{array}{c}\text { EV- } \\
(\mathrm{nE})\end{array}$ \\
\hline $\begin{array}{c}\text { GT- } \\
\text { DR }\end{array}$ & 11 & 12 & 172 & 24091 & 1063 & 680 & 1321 & 3 \\
\hline $\begin{array}{c}\text { NGT } \\
\text {-DR }\end{array}$ & 15 & 16 & 184 & 26274 & 1304 & 713 & 1408 & 4 \\
\hline $\begin{array}{c}\text { NO- } \\
\text { DR }\end{array}$ & 16 & 18 & 195 & 28631 & 1449 & 749 & 1496 & 7 \\
\hline
\end{tabular}

The amount of interrupted load power, aggregated at the monthly level, by load type, for the game-theoretic and nongame-theoretic DSM procurement scenarios are shown in Fig. 3. Also, by exemplifying the daily load power profile, where the annual peak load occurs, Fig. 4 illustrates how the deployment of both the game- and non-game-theoretic DR programs have contributed to the smoothening of the hourlybasis year-round load power profiles. As it was expected, the game-theoretic modeling of the DR provision framework leads to a flatter load power curve. This is mainly due to the awareness information provided on the system state (power outputs from renewable generators, available energy reserves, etc.) for the triggering of the DR events. In fact, the proposed game-theoretic model of DSM provides a platform for hedging against the deep uncertainties inherent in RSESs by endogenously determining the DR schedules - and not in an exogenous manner to the model. For example, as can be seen in Fig. 4, the optimization protocol distributes the available DR budget around different hours of the day - and not only to the hours marked as peak hours. Also, the assumptions made regarding the game type and the rational behavior of the players had a significant role in achieving the energy affordability targets by harnessing the potential of interruptible loads. For example, it is conceivable that the benefits of the proposed game-theoretic DR provision modeling framework would have been reduced, if the game was not played under the coalitional, non-zero-sum, tit-for-tat, Stackelberg conditions. 


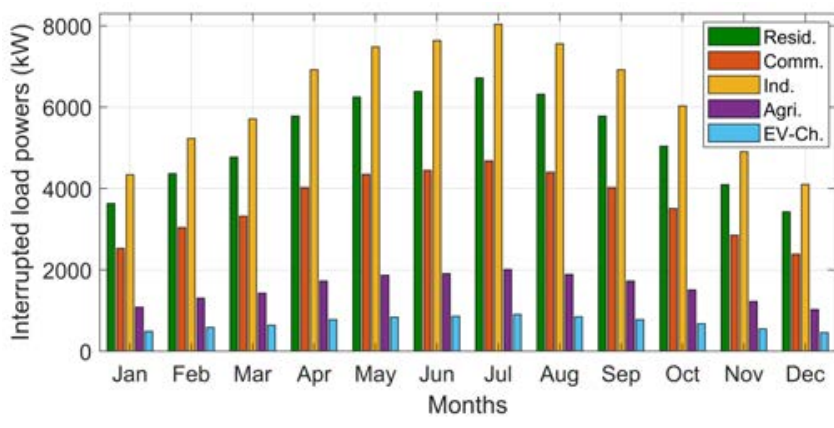

Fig. 3. Monthly values of the interrupted load powers.

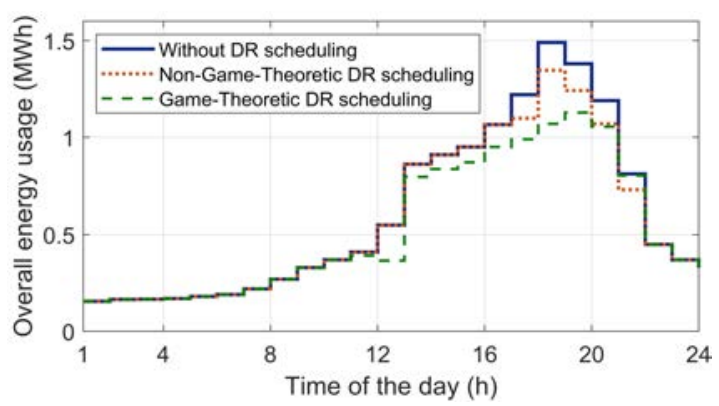

Fig. 4. Impact of DSM provision on the shape of the overall load profile.

\section{CONCLUSIONS AND FUTURE WORK}

A novel coordinated game-theoretic demand response service applied to the long-term economic planning of MGs was proposed to realistically model the consumers' engagement in the load interruption programs. Using a testcase MG system, it has been demonstrated that the proposed modeling framework could hold a significant implication for real-world applications. Given the prohibitive cost of renewable energy technologies, the coalitional management of the DR resources could play a key role in fostering the uptake of renewables; more specifically, the Game Theorycentered modeling of the DR provision plans can realize a sustainable and profitable business model and value chain for MGs, whilst not pulling the customers out of their comfort zones. Future work should focus on incorporating other DR resources (such as deferrable loads) in the proposed DSM approach, while considering several utilities operating under non-monopolistic conditions.

\section{REFERENCES}

[1] Transpower, "Planning, commitment needed for electricity transformation," 2018. https://www.transpower.co.nz/news/planningcommitment-needed-electricity-transformation.

[2] S. Mohseni and A. C. Brent, "Smart Grid and Zero-Emissions Energy Systems: The Need for a Multi-Dimensional Investment Planning Perspective," IEEE Smart Grid eNewsl., June 2018. https://doi.org/10.13140/RG.2.2.15832.55043.

[3] S. Mohseni, A. C. Brent, and D. Burmester "The Role of Artificial Intelligence in the Transition from Conventional Power Systems to Modernized Smart Grids," IEEE Smart Grid eNewsl., April 2019. https://doi.org/10.13140/RG.2.2.22543.43689.

[4] S. Mohseni, A. C. Brent, D. Burmester, and A. Chatterjee, "Optimal Sizing of an Islanded Micro-Grid Using Meta-Heuristic Optimization Algorithms Considering Demand-Side Management," in Proc. Australas. Univ. Power Eng. Conf., Auckland, New Zealand, 27-30 Nov. 2018, pp. 1-6.

[5] S. M. Moghaddas-Tafreshi, S. Mohseni, M. E. Karami, and S. Kelly "Optimal energy management of a grid-connected multiple energy carrier micro-grid," Appl. Therm. Eng., vol. 152, pp. 796-806, 2019.

[6] O. Erdinc, N. G. Paterakis, I. N. Pappi, A. G. Bakirtzis, and J. P. S. Catalão, "A new perspective for sizing of distributed generation and energy storage for smart households under demand response," Appl.
Energy, vol. 143, pp. 26-37, 2015.

[7] S. Kahrobaee, S. Asgarpoor, and W. Qiao, "Optimum sizing of distributed generation and storage capacity in smart households, "IEEE Trans. Smart Grid, vol. 4, no. 4, pp. 1791-1801, 2013.

[8] L. Zhu, Z. Yan, W. J. Lee, X. Yang, Y. Fu, and W. Cao, "Direct Load Control in Microgrids to Enhance the Performance of Integrated Resources Planning," IEEE Trans. Ind. Appl., vol. 51, pp. 1-8, 2015.

[9] A. Chauhan and R. P. Saini, "Size optimization and demand response of a stand-alone integrated renewable energy system," Energy, vol. 124, pp. 59-73, 2017.

[10] H. Hassanzadehfard, S. M. Moghaddas-Tafreshi, and S. M. Hakimi, "Optimization of grid-connected microgrid consisting of $\mathrm{PV} / \mathrm{FC} / \mathrm{UC}$ with considered frequency control," Turkish J. Electr. Eng. Comput. Sci., vol. 23, no. 1, pp. 1-16, 2015.

[11] S. Mohseni, A. C. Brent, and D. Burmester, "A demand responsecentred approach to the long-term equipment capacity planning of gridindependent micro-grids optimized by the moth-flame optimization algorithm," Energy Convers. Manag., vol. 200, 112105, 2019.

[12] N. I. Nwulu and X. Xia, "Implementing a model predictive control strategy on the dynamic economic emission dispatch problem with game theory based demand response programs," Energy, vol. 91, pp. 404-419, 2015.

[13] N. I. Nwulu and X. Xia, "Multi-objective dynamic economic emission dispatch of electric power generation integrated with game theory based demand response programs," Energy Convers. Manag., vol. 89, pp. 963-974, 2015.

[14] S. S. Reka and V. Ramesh, "A demand response modeling for residential consumers in smart grid environment using game theory based energy scheduling algorithm," Ain Shams Eng. J., vol. 7, no. 2, pp. 835-845, 2016.

[15] S. Mohseni, A. C. Brent, and D. Burmester, "A Reliability-Oriented Cost Optimisation Method for Capacity Planning of a Multi-Carrier Micro-Grid: A Case Study of Stewart Island, New Zealand," arXiv preprint, arXiv:1906.09544, 2019.

[16] H. Bartlett, "3000 Tarungi residents in power struggle," 2016. https://www.nzherald.co.nz/business/news/article.cfm?c id=3\&object id=11664395.

[17] A. C. Duman and Ö. Güler, "Techno-economic analysis of off-grid $\mathrm{PV} /$ wind/fuel cell hybrid system combinations with a comparison of regularly and seasonally occupied households," Sustain. Cities Soc., vol. 42, pp. 107-126, 2018.

[18] H. W. Teetz, T. M. Harms, and T. W. von Backström, "Assessment of the wind power potential at SANAE IV base, Antarctica: A technical and economic feasibility study," Renew. Energy, vol. 28, pp. 20372061, 2003

[19] S. Mohseni, A. C. Brent, and D. Burmester, "A Sustainable Energy Investment Planning Model Based on the Micro-Grid Concept Using Recent Metaheuristic Optimization Algorithms," in Proc. 2019 IEEE Congress on Evolutionary Computation, Wellington, New Zealand, 10-13 Jun. 2019, pp. 219-226.

[20] S. Mohseni, A. C. Brent, D. Burmester, and A. Chatterjee, "Stochastic Optimal Sizing of Micro-Grids Using the Moth-Flame Optimization Algorithm," in Proc. 2019 IEEE Power \& Energy Society General Meeting, Atlanta, GA, USA, 4-8 Aug. 2019, pp. 1-5.

[21] S. Mohseni and S. M. Moghaddas-Tafreshi, "Development of a multiagent system for optimal sizing of a commercial complex microgrid," arXiv preprint, arXiv:1811.12553, 2018.

[22] S. Mohseni and S.M. Moghaddas-Tafreshi, "A multi-agent system for optimal sizing of a cooperative self-sustainable multi-carrier microgrid," Sustain. Cities Soc., vol. 38, pp. 452-465, 2018.

[23] S. Mohseni and S. M. Moghaddas-Tafreshi, "A multi-agent approach to optimal sizing of a combined heating and power microgrid," arXiv preprint, arXiv:1812.11076, 2018.

[24] CliFlo: NIWA's National Climate Database on the Web.

[25] J. Anderson. Pulling the Plug on Network Congestion. University of Otago, 2009.

[26] Ministry of Business, Innovation, and Employment. Energy in New Zealand: Energy Overview 2018. [Data Collection]. Available: https://figure.nz/chart/acDyabkYBz9fsVN5-0sNydHH33nuxuqKj.

[27] S. M. Moghaddas-Tafreshi, M. Jafari, S. Mohseni, and S. Kelly, "Optimal operation of an energy hub considering the uncertainty associated with the power consumption of plug-in hybrid electric vehicles using information gap decision theory," Int. J. Electr. Power Energy Syst., vol. 112, pp. 92-108, 2019 